Check for updates

Cite this: RSC Adv., 2019, 9, 17891

\title{
One-step electrodeposition of cerium-doped nickel hydroxide nanosheets for effective oxygen generation $\dagger$
}

\author{
Gang Fang, ${ }^{a}$ Jinhua Cai, ${ }^{b}$ Zhipeng Huang (iD *c and Chi Zhang (D) ${ }^{c}$ \\ Efficient electrocatalysts catalyzing oxygen evolution reaction (OER) in alkaline media is highly desirable for \\ large-scale hydrogen production from water splitting. Here we report the direct electrodeposition of \\ cerium-doped nickel hydroxide nanosheets on carbon fiber paper and its prominent performance in \\ catalyzing the OER. The composite generates a current density of $100 \mathrm{~mA} \mathrm{~cm}{ }^{-2}$ at an overpotential of \\ $320 \mathrm{mV}$, rivaling the performance of most reported OER catalysts and commercially available $\mathrm{RuO}_{2} . \mathrm{X}-$ \\ ray photoelectron spectroscopy analysis shows strong electronic interaction between $\mathrm{Ni}(\mathrm{OH})_{2}$ and $\mathrm{CeO}_{2}$, \\ making a great contribution to the OER enhancement.
}

Received 10th April 2019

Accepted 29th May 2019

DOI: $10.1039 / \mathrm{c} 9 \mathrm{ra0} 2682 \mathrm{~g}$

rsc.li/rsc-advances

In general, doping catalysts with foreign elements can

\section{Introduction}

The fast-growing world population results in a significant increase in energy consumption. Due to the limited resource of fossil energy, the development of new technologies to provide clean, affordable, and renewable energy is urgently required. ${ }^{1,2}$ In the current hydrocarbon economic transformation, hydrogen is being actively promoted as a future energy carrier. ${ }^{3}$ In particular, electrochemical water splitting is being regarded as a green and sustainable route to convert water into hydrogen..$^{3-5}$ However, because of the oxidative half-reaction, the oxygen evolution reaction (OER), is a 4electron process that forms only one oxygen molecule, the kinetics of the OER is sluggish, and the OER has always been thought as the rate-limiting step in water splitting. ${ }^{6-9}$ Therefore, there is a need to develop an effective OER electrocatalyst, which possesses lower overpotential, faster catalytic kinetics, and therefore improves the energy conversion efficiency. ${ }^{10,11}$ Among many reported OER catalysts, $\mathrm{RuO}_{2}$ and $\mathrm{IrO}_{2}$ are the most active OER electrocatalysts, however, their scarcity and high cost greatly limit their large-scale applications. ${ }^{12,13}$ Substantial advances have been made in exploiting nonprecious oxygen-evolving catalysts, among which some transition metal hydr(oxy)oxides/oxides show superior intrinsic activity. ${ }^{14-19}$

${ }^{a}$ School of Chemistry and Chemical Engineering, Jiangsu University, Zhenjiang, 212013, P. R. China

${ }^{b}$ College of Chemistry \& Chemical Engineering, Jinggangshan University, Jian, Jiangxi Province 343009, P. R. China

${ }^{\prime}$ School of Chemical Science and Engineering, Tongii University, Shanghai, 200092, P. R. China. E-mail: zphuang@tongji.edu.cn

$\dagger$ Electronic supplementary information (ESI) available. See DOI: $10.1039 / \mathrm{c} 9 \mathrm{ra} 02682 \mathrm{~g}$ ffectively modify electronic structure and reliably introduce defects to facilitate the adsorption and conversion of active intermediates with a lower energy barrier for OER.$^{20}$ Transition metals, especially $3 \mathrm{~d}$ transition metals such as Fe, Mn, $\mathrm{Cr}$, and Co are widely used as dopants to regulate the chemical state of electrocatalysts. ${ }^{21-26}$ Recently, several groups reported the improvement of the performance of catalysts in hydrogen and oxygen generation by doping cerium into the host catalyst or constructing a heterogeneous structure between $\mathrm{CeO}_{2}$ and the active catalysts. ${ }^{27-34}$ For instance, $\mathrm{CeO}_{2}$-cluster-doped $\mathrm{NiO}$ shows better performance in the OER than $\mathrm{CeO}_{2}$ cluster surface-loaded $\mathrm{NiO}$, due to promoted oxygen storage capacity and modified electronic structure of the active sites. ${ }^{35}$ The promotion of $\mathrm{FeOOH}$ catalysts for OER by the integration of $\mathrm{CeO}_{2}$ has been demonstrated due to the larger oxygen storage capacity of $\mathrm{CeO}_{2}$ and electron interaction between $\mathrm{CeO}_{2}$ and electrocatalysts. ${ }^{30}$ Another work has been represented by depositing a protective thin $\mathrm{CeO}_{2}$ layer on $\mathrm{NiFeO}_{x}$ to improve stability by preventing ion leaching. ${ }^{36}$ We have also demonstrated that the introduction of Ce induced the amorphourization of $\mathrm{CoO}_{x}$ and brought new oxygen defects. ${ }^{37}$ Although various approaches have been developed to introduce cerium into host catalysts, a convenient method for the one-step synthesis of metal hydr(oxy)oxides/oxides catalysts remains definitely unexploited.

In this study, we reported a convenient fabrication of OER electrocatalyst by one-step electrodeposition of cerium doped nickel hydroxide nanosheets (NSs) on carbon fiber paper (CFP) and its effective catalytic activity in the OER. The electrodeposited freestanding electrode possesses advantageous active site utilization and simple fabrication over conventional powder electrocatalysts, which is physically 
mixed with polymeric binder and conducting agent to make a slurry for coating on current collector. ${ }^{38}$ The optimization of the molar ratio of $\mathrm{Ni}$ to $\mathrm{Ce}$ in the deposition solution revealed that a $30: 1 \mathrm{Ni}$ : Ce solution generated a film with the best performance. With the introduction of $\mathrm{Ce}$, the optimized $\mathrm{Ni}(\mathrm{OH})_{2} \cdot 0.75 \mathrm{H}_{2} \mathrm{O}-\mathrm{CeO}_{2}$ NSs showed an tremendous increase in OER performance with the lowest overpotential of $320 \mathrm{mV}$ at $100 \mathrm{~mA} \mathrm{~cm}{ }^{-2}$ and Tafel slope of $126 \mathrm{mV} \mathrm{dec}^{-1}$ in alkaline electrolyte, as compared with that of $\mathrm{Ni}(\mathrm{OH})_{2} \cdot 0.75 \mathrm{H}_{2} \mathrm{O} \mathrm{NSs}\left(\eta_{100}=460 \mathrm{mV}\right.$, Tafel slope $=185 \mathrm{mV}$ $\mathrm{dec}^{-1}$ ) deposited by the same method. Meanwhile, the $\mathrm{Ni}(\mathrm{OH})_{2} \cdot 0.75 \mathrm{H}_{2} \mathrm{O}-\mathrm{CeO}_{2} \mathrm{NS}$ showed prominent stability at a high reaction rate for a long time and the faradaic efficiency of $92 \%$ during water oxidation. These results not only present a new 3d transition metal hydroxide doped with cerium as an effective OER catalysts, but also introduce a facile method for one step electrodeposition synthesis of electrocatalysts loaded onto conductive support.

\section{Experimental}

\section{Reagents}

Nickel nitrate hexahydrate $\left(\mathrm{Ni}\left(\mathrm{NO}_{3}\right)_{2} \cdot 6 \mathrm{H}_{2} \mathrm{O}, \mathrm{AR}\right)$, cerium nitrate hexahydrate $\left(\mathrm{Ce}\left(\mathrm{NO}_{3}\right)_{3} \cdot 6 \mathrm{H}_{2} \mathrm{O}, \mathrm{REO}\right)$, acetone $\left(\mathrm{CH}_{3} \mathrm{COCH}_{3}, \mathrm{AR}\right)$, and ethanol $\left(\mathrm{C}_{2} \mathrm{H}_{5} \mathrm{OH}, \mathrm{AR}\right)$ were purchased from Tansoole Co., Ltd. CFP was commercially available from Hesen Co., Ltd. All chemicals were used as received without further purification.

\section{Synthesis}

Prior to synthesis, a few pieces of CFP $(1 \mathrm{~cm} \times 2 \mathrm{~cm})$ were washed ultrasonically with acetone, ethanol, and deionized water every 10 minutes in sequence. $\mathrm{Ni}(\mathrm{OH})_{2} \cdot 0.75 \mathrm{H}_{2} \mathrm{O}-\mathrm{CeO}_{2}$ NSs were directly electrodeposited on the CFP in a threeelectrode cell, using the CFP as the working electrode, Pt as the counter electrode, and $\mathrm{Hg} / \mathrm{Hg}_{2} \mathrm{Cl}_{2}$ as the reference electrode. The electrolyte solutions with different atomic ratio of $\mathrm{Ni}$ to Ce were prepared by mixing $10 \mathrm{mmol} \mathrm{Ni}\left(\mathrm{NO}_{3}\right)_{2} \cdot 6 \mathrm{H}_{2} \mathrm{O}$ with different amounts of $\mathrm{Ce}\left(\mathrm{NO}_{3}\right)_{3} \cdot 6 \mathrm{H}_{2} \mathrm{O}$ (i.e., , 4, 1, 0.33, 0.25 $\mathrm{mmol}$ ) into $100 \mathrm{ml}$ deionized water and stirring them for $1 \mathrm{~h}$. Electrodeposition was carried out in a three electrode system as described above using the potential static technique at $-1.0 \mathrm{~V}$ for $20 \mathrm{~min}$ at room temperature; the corresponding electrodes are denoted as $\mathrm{Ni}(\mathrm{OH})_{2} \cdot 0.75 \mathrm{H}_{2} \mathrm{O}-\mathrm{CeO}_{2}(2.5: 1)$ NSs, $\mathrm{Ni}(\mathrm{OH})_{2} \cdot 0.75 \mathrm{H}_{2} \mathrm{O}-\mathrm{CeO}_{2}(10: 1) \mathrm{NSs}, \mathrm{Ni}(\mathrm{OH})_{2} \cdot 0.75 \mathrm{H}_{2} \mathrm{O}-$ $\mathrm{CeO}_{2}(30: 1) \mathrm{NSs}$, and $\mathrm{Ni}(\mathrm{OH})_{2} \cdot 0.75 \mathrm{H}_{2} \mathrm{O}-\mathrm{CeO}_{2}(40: 1) \mathrm{NSs}$, respectively. For the synthesis of $\mathrm{Ni}(\mathrm{OH})_{2} \cdot 0.75 \mathrm{H}_{2} \mathrm{O}$ NSs, the method is similar to that of $\mathrm{Ni}(\mathrm{OH})_{2} \cdot 0.75 \mathrm{H}_{2} \mathrm{O}-\mathrm{CeO}_{2} \mathrm{NSs}$ without adding the $\mathrm{Ce}\left(\mathrm{NO}_{3}\right)_{3} \cdot 6 \mathrm{H}_{2} \mathrm{O}$ into the electrolyte. After deposition, the as-prepared products were washed with deionized water and absolute ethanol and then dried at $60{ }^{\circ} \mathrm{C}$ for $10 \mathrm{~h}$. The mass loading of the products on CFP was approximately $6.8,4.2,7.5,5.9$, and $5.3 \mathrm{mg} \mathrm{cm} \mathrm{cm}^{-2}$ for $\mathrm{Ni}(\mathrm{OH})_{2} \cdot 0.75 \mathrm{H}_{2} \mathrm{O}-\mathrm{CeO}_{2}(2.5: 1) \mathrm{NSs}, \mathrm{Ni}(\mathrm{OH})_{2} \cdot 0.75 \mathrm{H}_{2} \mathrm{O}-\mathrm{CeO}_{2}$ $(10: 1) \mathrm{NSs}, \mathrm{Ni}(\mathrm{OH})_{2} \cdot 0.75 \mathrm{H}_{2} \mathrm{O}-\mathrm{CeO}_{2}(30: 1) \mathrm{NSs}, \mathrm{Ni}(\mathrm{OH})_{2}-$ $\cdot 0.75 \mathrm{H}_{2} \mathrm{O}-\mathrm{CeO}_{2}(40: 1) \mathrm{NSs}$ and $\mathrm{Ni}(\mathrm{OH})_{2} \cdot 0.75 \mathrm{H}_{2} \mathrm{O}$ NSs, respectively. These results were obtained by weighing the electrodes carefully before and after deposition.

\section{Characterization}

The morphology of the samples was characterized with fieldemission scanning electron microscopy (FE-SEM, S-4800, Hitachi) and transmission electron microscopy (TEM, Tecnai G2 F30 S-TWIN, FEI). Powder X-ray diffraction (XRD) patterns were recorded on a Bruker D8 Advance diffractometer with $\mathrm{Cu} \mathrm{K} \alpha$ radiation $(\lambda=1.5406 \AA)$. The surface characteristics of the samples were investigated using ESCALAB250Xi X-ray photoelectron spectrometer (XPS).

\section{Electrochemical measurement}

Electrochemistry measurements were carried out on an electrochemistry workstation ( $\mathrm{CHI} 760 \mathrm{E}, \mathrm{CH}$ Instrument) in a threeport glass chamber. A mercury-mercury oxide electrode (MOE) was used as a reference electrode, and a graphite rod was used as a counter electrode. The counter electrode was separated from the chamber of working electrode by a porous glass frit. The electrolyte is an aqueous $\mathrm{KOH}$ solution (1 M). The RHE was determined by the open circuit potential of a clean Pt electrode in the solution of interest bubbled with $\mathrm{H}_{2}$ (99.999\%). A scan rate of $5 \mathrm{mV} \mathrm{S}^{-1}$ was adopted for the measurement of polarization curves. The measured potentials were corrected with ohmic drop $(i R)$, where $i$ is the current corresponding to the experimental potential and $R$ is the uncompensated cell resistance estimated by current interrupt method. The apparent Tafel slope was derived from the $i R$-corrected polarization curve by fitting experimental data to the equation $\eta=a+b \log j$, where $\eta$ is the $i R$-corrected potential, $a$ is the Tafel constant, $b$ is the Tafel slope, and $j$ is the current density. Electrochemical impedance spectroscopy (EIS) were carried out at $1.55 \mathrm{~V} v s$. RHE in the frequency range of $10^{-2}$ to $10^{6} \mathrm{~Hz}$ with $10 \mathrm{mV}$ sinusoidal perturbations and 12 steps per decade. Faradaic efficiency was measured by a method reported in our previous publications..$^{39-41}$

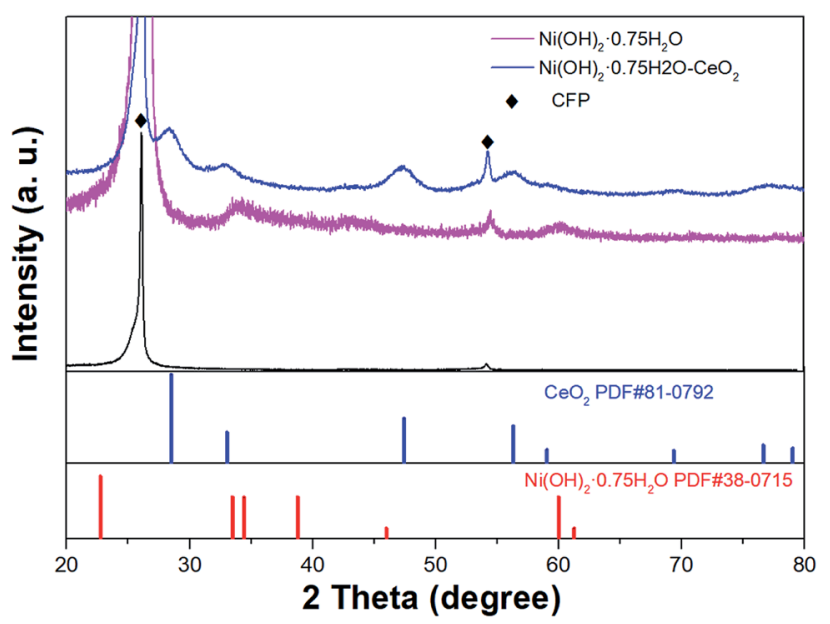

Fig. 1 XRD patterns of $\mathrm{Ni}(\mathrm{OH})_{2} \cdot 0.75 \mathrm{H}_{2} \mathrm{O}, \mathrm{Ni}(\mathrm{OH})_{2} \cdot 0.75 \mathrm{H}_{2} \mathrm{O}-\mathrm{CeO}_{2}$ and bare CFP. 


\section{Results and discussion}

The XRD pattern was recorded to determine the component of products. Fig. 1 gives the XRD pattern of the two samples resulted from electro-deposition, including $\mathrm{Ni}(\mathrm{OH})_{2} \cdot 0.75 \mathrm{H}_{2} \mathrm{O}$ and $\mathrm{Ni}(\mathrm{OH})_{2} \cdot 0.75 \mathrm{H}_{2} \mathrm{O}-\mathrm{CeO}_{2}$. In spite of the poor crystallinity of the deposited samples, both of the two XRD patterns have a number of peaks that can be indexed to $\mathrm{Ni}(\mathrm{OH})_{2} \cdot 0.75 \mathrm{H}_{2} \mathrm{O}$. The presence of $\mathrm{Ni}(\mathrm{OH})_{2} \cdot 0.75 \mathrm{H}_{2} \mathrm{O}$ NSs were further examined using the HRTEM images. The detailed elemental composition and oxidation state of the hybrid arrays were further characterized using XPS analysis. The diffraction pattern for the as-prepared porous $\mathrm{Ni}(\mathrm{OH})_{2} \cdot 0.75 \mathrm{H}_{2} \mathrm{O}-\mathrm{CeO}_{2}$ NSs arrays on $\mathrm{CFP}$, represented by the purple line, has seven obvious peaks at $28.5^{\circ}$, $33.0^{\circ}, 47.5^{\circ}, 56.3^{\circ}, 59.0^{\circ}, 69.4^{\circ}, 76.7^{\circ}$ and $79.0^{\circ}$, corresponding to (1 11 1), (2 $\left.\begin{array}{lll}2 & 0\end{array}\right),\left(\begin{array}{lll}2 & 2 & 0\end{array}\right),\left(\begin{array}{lll}3 & 1 & 1\end{array}\right),\left(\begin{array}{lll}2 & 2 & 2\end{array}\right),\left(\begin{array}{lll}0 & 0 & 0\end{array}\right),\left(\begin{array}{lll}3 & 3 & 1\end{array}\right)$, and (4 $\left.\begin{array}{ll}2 & 0\end{array}\right)$ of cubic $\mathrm{CeO}_{2}$ (JCPDS PDF81-0792). It is therefore suggested that $\mathrm{CeO}_{2}$ was successfully doped into the $\mathrm{Ni}(\mathrm{OH})_{2} \cdot 0.75 \mathrm{H}_{2} \mathrm{O}$ NSs. Owing to $\mathrm{Ni}(\mathrm{OH})_{2} \cdot 0.75 \mathrm{H}_{2} \mathrm{O}$ NSs and $\mathrm{Ni}(\mathrm{OH})_{2} \cdot 0.75 \mathrm{H}_{2} \mathrm{O}-\mathrm{CeO}_{2}$ NSs growth on the CFP, peaks corresponding to the CFP were labeled by rhomboids.

The morphologies of NSs of $\mathrm{Ni}(\mathrm{OH})_{2} \cdot 0.75 \mathrm{H}_{2} \mathrm{O}$ and $\mathrm{Ni}(\mathrm{OH})_{2} \cdot 0.75 \mathrm{H}_{2} \mathrm{O}-\mathrm{CeO}_{2}$ supported by CFP were examined with the SEM. Fig. $2 \mathrm{a}$ and $\mathrm{b}$ show that $\mathrm{Ni}(\mathrm{OH})_{2} \cdot 0.75 \mathrm{H}_{2} \mathrm{O}-\mathrm{CeO}_{2}$ nanosheets were homogenously deposited on the surface of CFP with a three-dimensional (3D) open structure. Cracks can be found on the surface of CFP (shown in the Fig. S1†), with a width of $1.6 \mu \mathrm{m}$, which may be due to drying in the oven. The thickness of the sample on the surface of CFP was estimated to be $3 \mu \mathrm{m}$, according to the crack exposing the cross-section of the sample (shown in the Fig. S1†). Energy-dispersive X-ray spectroscopy (EDX) confirms the presences of $\mathrm{Ni}$, Ce and $\mathrm{O}$ in the $\mathrm{Ni}(\mathrm{OH})_{2} \cdot 0.75 \mathrm{H}_{2} \mathrm{O}-\mathrm{CeO}_{2}$ NSs (Fig. S2 in the ESI $\dagger$ ). With increasing $\mathrm{Ce}$ concentration, the atomic ratio of $\mathrm{Ni}$ to $\mathrm{Ce}$ changes from $4.1: 1$ to $2.6: 1$ to $2.27: 1$ to $1.1: 1$ (shown in the

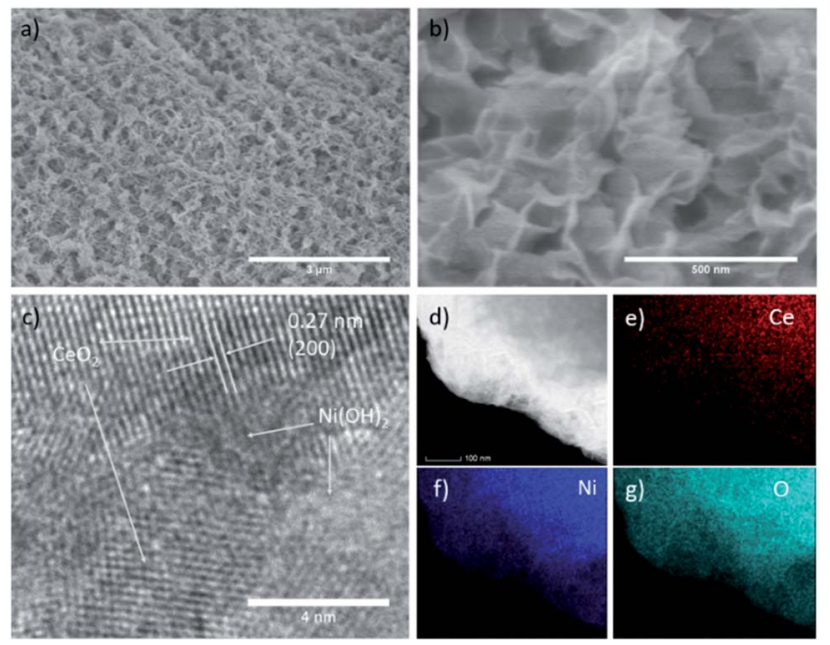

Fig. 2 (a and b) SEM images of $\mathrm{Ni}(\mathrm{OH})_{2} \cdot 0.75 \mathrm{H}_{2} \mathrm{O}-\mathrm{CeO}_{2}$. (c) HRTEM images of $\mathrm{Ni}(\mathrm{OH})_{2} \cdot 0.75 \mathrm{H}_{2} \mathrm{O}-\mathrm{CeO}_{2}$. (d) Dark-field STEM image of $\mathrm{Ni}(\mathrm{OH})_{2} \cdot 0.75 \mathrm{H}_{2} \mathrm{O}-\mathrm{CeO}_{2}$ and corresponding elemental mapping images of (e) $\mathrm{Ce},(f) \mathrm{Ni}$, (g) $\mathrm{O}$.
Table S1 $\dagger$ ), of which the values were determined by ICP-MS. The microstructures of $\mathrm{Ni}(\mathrm{OH})_{2} \cdot 0.75 \mathrm{H}_{2} \mathrm{O}-\mathrm{CeO}_{2}$ NSs were further assessed by TEM. Fig. 2c shows a high resolution TEM (HRTEM) image of $\mathrm{Ni}(\mathrm{OH})_{2} \cdot 0.75 \mathrm{H}_{2} \mathrm{O}-\mathrm{CeO}_{2}$ NSs, which shows wellresolved lattice fringes with an inter-plane distance of $0.27 \mathrm{~nm}$, which corresponds to the (200) plane of $\mathrm{CeO}_{2}$, indicating the successfully introduction of $\mathrm{CeO}_{2}$ in the composite. And the part of the lattice that is not obvious corresponds to $\mathrm{Ni}(\mathrm{OH})_{2} \cdot 0.75 \mathrm{H}_{2} \mathrm{O}$, which is the same as HRTEM images of $\mathrm{Ni}(\mathrm{OH})_{2} \cdot 0.75 \mathrm{H}_{2} \mathrm{O}$ NSs (Fig. S4a in the ESI $\dagger$ ). The dark-field STEM image and the corresponding EDS mapping of the $\mathrm{Ni}(\mathrm{OH})_{2} \cdot 0.75 \mathrm{H}_{2} \mathrm{O}-\mathrm{CeO}_{2}$ NSs are shown in Fig. $2 \mathrm{~d}-\mathrm{f}$. The element-mapping images of $\mathrm{Ce}, \mathrm{Ni}$, and $\mathrm{O}$ further confirm the $\mathrm{Ni}$ and $\mathrm{Ce}$ are homogeneously mixed with each other. For comparison, the pure $\mathrm{Ni}(\mathrm{OH})_{2} \cdot 0.75 \mathrm{H}_{2} \mathrm{O}$ NSs grown on CFP was also synthesized by the same electro-deposition method without Ce source. The morphology of $\mathrm{Ni}(\mathrm{OH})_{2} \cdot 0.75 \mathrm{H}_{2} \mathrm{O}$ NSs is analogous to that of $\mathrm{Ni}(\mathrm{OH})_{2} \cdot 0.75 \mathrm{H}_{2} \mathrm{O}-\mathrm{CeO}_{2} \mathrm{NSs}$, as shown by SEM images (Fig. S3 and S4 in the ESI $†$ ).

To demonstrate the activity of Ce for OER, the polarization curves were measured. The catalytic activity of $\mathrm{Ni}(\mathrm{OH})_{2}-$ $\cdot 0.75 \mathrm{H}_{2} \mathrm{O}-\mathrm{CeO}_{2} \mathrm{NSs}$ and $\mathrm{Ni}(\mathrm{OH})_{2} \cdot 0.75 \mathrm{H}_{2} \mathrm{O}$ NSs grown on $\mathrm{CFP}$ electrodes were studied initially by linear sweep voltammetry (LSV) in a standard three-electrode cell. A graphite rod was adopted as a counter electrode. All measured potentials were corrected with $i R$ drop. Fig. 3a shows that the polarization curves of $\mathrm{Ni}(\mathrm{OH})_{2} \cdot 0.75 \mathrm{H}_{2} \mathrm{O}$ and $\mathrm{Ni}(\mathrm{OH})_{2} \cdot 0.75 \mathrm{H}_{2} \mathrm{O}-\mathrm{CeO}_{2}$ with different atomic ratio of $\mathrm{Ni}$ to $\mathrm{Ce}$. The overpotential required for a current density of $100 \mathrm{~mA} \mathrm{~cm}{ }^{-2}\left(\eta_{100}\right)$ is $460 \mathrm{mV}$ for $\mathrm{Ni}(\mathrm{OH})_{2} \cdot 0.75 \mathrm{H}_{2} \mathrm{O}$ NSs. Once Ce source was doped into the samples, the $\eta_{100}$ of these $\mathrm{Ni}(\mathrm{OH})_{2} \cdot 0.75 \mathrm{H}_{2} \mathrm{O}$ NSs changes with
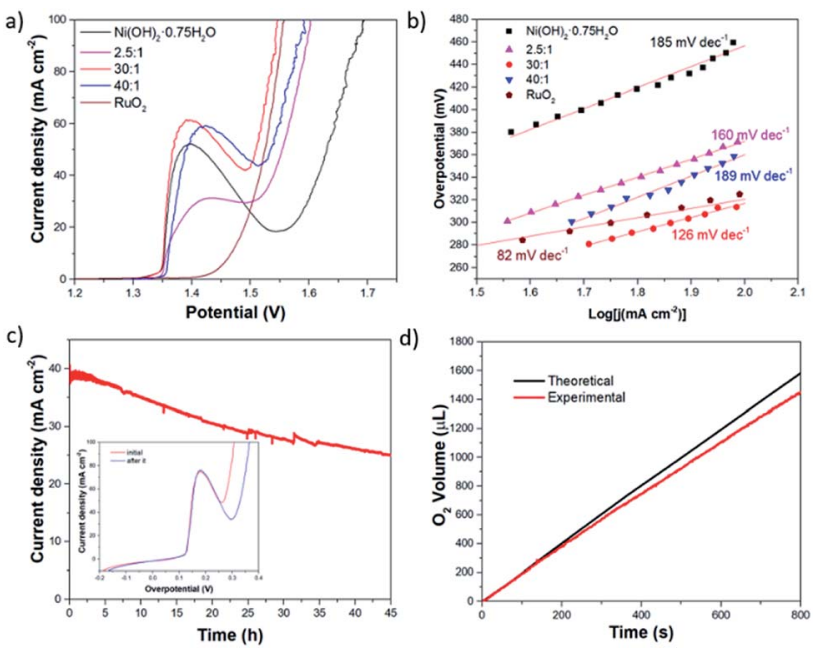

Fig. 3 The electrocatalytic performance of the catalysts. (a) Polarization curves and (b) Tafel of $\mathrm{Ni}(\mathrm{OH})_{2} \cdot 0.75 \mathrm{H}_{2} \mathrm{O}-\mathrm{CeO}_{2}(2.5: 1)$, $\mathrm{Ni}(\mathrm{OH})_{2} \cdot 0.75 \mathrm{H}_{2} \mathrm{O}-\mathrm{CeO}_{2}(30: 1), \mathrm{Ni}(\mathrm{OH})_{2} \cdot 0.75 \mathrm{H}_{2} \mathrm{O}-\mathrm{CeO}_{2}$ (40:1), $\mathrm{Ni}(\mathrm{OH})_{2} \cdot 0.75 \mathrm{H}_{2} \mathrm{O}$ and $\mathrm{RuO}_{2}$ (c) current-time curve of $\mathrm{Ni}(\mathrm{OH})_{2}-$ $\cdot 0.75 \mathrm{H}_{2} \mathrm{O}-\mathrm{CeO}_{2}(30: 1)$ recorded in a potentiostatic electrolysis experiment. Inset of (c) shows the LSV curves measured before and after potentiostatic electrolysis experiment. (d) Comparison of theoretical and detected volume of oxygen generated from a potentiostatic electrolysis. All potentials are corrected with $i R$ drop. 
a huge decrease. With the increased atomic ratio of $\mathrm{Ni}$ to $\mathrm{Ce}$, the OER activity appears as volcano-like trend, in which the $\mathrm{Ni}(\mathrm{OH})_{2} \cdot 0.75 \mathrm{H}_{2} \mathrm{O}-\mathrm{CeO}_{2}(30: 1)$ NSs endows the best OER performance among the tested catalysts. The $\eta_{100}$ is as small as $320 \mathrm{mV}$, making it among the best OER catalysts (shown in the Table S2 $\dagger$ ). To gain more insight on the OER activity, Tafel plots derived from polarization curves were constructed (Fig. 3b). The resulting Tafel slope of $\mathrm{Ni}(\mathrm{OH})_{2} \cdot 0.75 \mathrm{H}_{2} \mathrm{O}-\mathrm{CeO}_{2}(30: 1)$ NSs was $126 \mathrm{mV} \mathrm{dec}^{-1}$, which is smaller than that of $\mathrm{Ni}(\mathrm{OH})_{2} \cdot 0.75 \mathrm{H}_{2} \mathrm{O}$ NSs $\left(185 \mathrm{mV} \mathrm{dec}{ }^{-1}\right), \mathrm{Ni}(\mathrm{OH})_{2} \cdot 0.75 \mathrm{H}_{2} \mathrm{O}-\mathrm{CeO}_{2}(40: 1)$ NSs (189 $\left.\mathrm{mV} \mathrm{dec}{ }^{-1}\right)$, and $\mathrm{Ni}(\mathrm{OH})_{2} \cdot 0.75 \mathrm{H}_{2} \mathrm{O}-\mathrm{CeO}_{2}(2.5: 1) \mathrm{NSs}$ $\left(160 \mathrm{mV} \mathrm{dec}{ }^{-1}\right)$, indicating that the $\mathrm{Ni}(\mathrm{OH})_{2} \cdot 0.75 \mathrm{H}_{2} \mathrm{O}-\mathrm{CeO}_{2}$ (30:1) NSs exhibited better OER activity.

Long-term stability in oxygen generation is the prerequisite of a practically useful OER catalyst. The long-term stability of the $\mathrm{Ni}(\mathrm{OH})_{2} \cdot 0.75 \mathrm{H}_{2} \mathrm{O}-\mathrm{CeO}_{2}$ NSs was demonstrated by the chronoamperometry. The $\mathrm{Ni}(\mathrm{OH})_{2} \cdot 0.75 \mathrm{H}_{2} \mathrm{O}-\mathrm{CeO}_{2}(30: 1) \mathrm{NSs}$ can maintain $64 \%$ of its capability in catalyzing the OER in longterm water electrolysis after 45 hours, shown in Fig. 3c. And, the $\eta_{100}$ is increased from $310 \mathrm{mV}$ to $365 \mathrm{mV}$ after the long-time electrolysis test (the inset plot in Fig. 3c). The decay of $\eta_{100}$ is about $18 \%$. The SEM images of $\mathrm{Ni}(\mathrm{OH})_{2} \cdot 0.75 \mathrm{H}_{2} \mathrm{O}-\mathrm{CeO}_{2}(30: 1)$ NSs subjected to long-term potentiostatic electrolysis is shown in Fig. S5 in the ESI, $\uparrow$ which shows that most $\mathrm{Ni}(\mathrm{OH})_{2} \cdot 0.75 \mathrm{H}_{2} \mathrm{O}-$ $\mathrm{CeO}_{2}(30: 1)$ NSs maintain their 3D open structure with some nanosheets peeling off on the surface of the catalyst. EDX shows that the atomic ratio of $\mathrm{Ni}$ to Ce changes from 6.29:1 to 10.24 : 1 with some loss of Ce (Fig. S6 in the ESI $\dagger$ ), which may be one of the reasons for degradation of catalyst performance.

The faradaic efficiency of $\mathrm{Ni}(\mathrm{OH})_{2} \cdot 0.75 \mathrm{H}_{2} \mathrm{O}-\mathrm{CeO}_{2}(30: 1)$ NSs during $\mathrm{O}_{2}$ evolution was evaluated by the comparison of the volume of generated gas and the theoretical volume in the potentiostatic electrolysis measurement, shown in Fig. 3d. The theoretical volumes were computed by assuming that all electrons passing through the circuit participate in the oxidation reaction of $\mathrm{OH}^{-}\left(4 \mathrm{OH}^{-}-4 \mathrm{e}^{-} \rightarrow \mathrm{O}_{2} \uparrow+2 \mathrm{H}_{2} \mathrm{O}\right)$, and the experiment volume was detected by the water displacement method. During electrolysis for $4000 \mathrm{~s}$, the experiment and theoretical volumes are in good accordance, suggesting 92\% faradaic efficiency.

To understand the excellent OER activity, EIS was tested at the potential of $1.55 \mathrm{~V} v s$. RHE. The results are shown in the Nyquist curves in the Fig. 4a, where the data were fit using an equivalent circuit shown in Fig. S7 and Table S3 in the ESI. $\uparrow$ The semicircle in the low frequency range is related to the faradaic
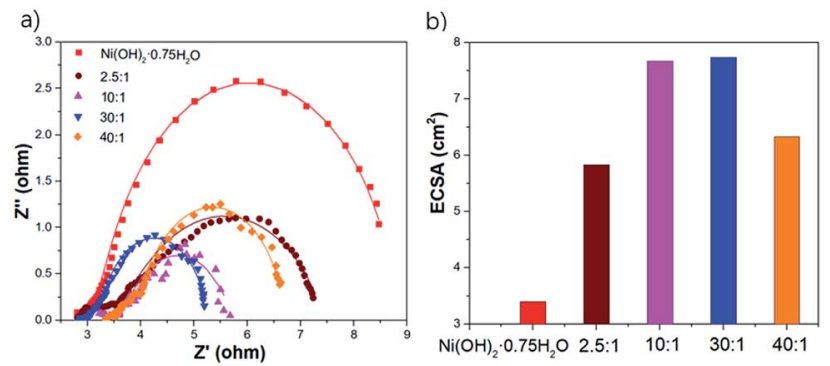

Fig. 4 (a) The Nyquist curves, (b) the ECSA of different samples. process (OER) on electrocatalyst surface. Corresponding resistance element is charge transfer resistance $\left(R_{\mathrm{ct}}\right) . R_{\mathrm{ct}}$ is usually used as an indicator of OER kinetics, a smaller $R_{\mathrm{ct}}$ corresponds to a faster OER process. As shown in the Fig. $4 \mathrm{a}$, the $R_{\mathrm{ct}}$ is decreased with the introduction of Ce to $\mathrm{Ni}(\mathrm{OH})_{2} \cdot 0.75 \mathrm{H}_{2} \mathrm{O} \mathrm{NSs}$, and the $R_{\text {ct }}$ of $\mathrm{Ni}(\mathrm{OH})_{2} \cdot 0.75 \mathrm{H}_{2} \mathrm{O}-\mathrm{CeO}_{2}(30: 1) \mathrm{NSs}(0.856 \Omega)$ is smaller than those of $\mathrm{Ni}(\mathrm{OH})_{2} \cdot 0.75 \mathrm{H}_{2} \mathrm{O}$ NSs $\left(\begin{array}{ll}1.317 \Omega & \Omega\end{array}\right)$, $\mathrm{Ni}(\mathrm{OH})_{2} \cdot 0.75 \mathrm{H}_{2} \mathrm{O}-\mathrm{CeO}_{2} \quad(10: 1) \quad \mathrm{NSs} \quad(0.928 \Omega), \quad \mathrm{Ni}(\mathrm{OH})_{2}-$ $\cdot 0.75 \mathrm{H}_{2} \mathrm{O}-\mathrm{CeO}_{2}(40: 1)$ NSs $(0.948 \Omega)$ and $\mathrm{Ni}(\mathrm{OH})_{2} \cdot 0.75 \mathrm{H}_{2} \mathrm{O}-$ $\mathrm{CeO}_{2}(2.5: 1)$ NSs $(1.177 \Omega)$ under the same condition, suggesting that $\mathrm{Ni}(\mathrm{OH})_{2} \cdot 0.75 \mathrm{H}_{2} \mathrm{O}-\mathrm{CeO}_{2}(30: 1)$ NSs possesses the fast electron transport ability for OER.

Electrochemically active surface area (ECSA) should play an important role in the high electrocatalytic performance, and it was derived from the specific capacitance measured by cyclic voltammetry (CV) scans (Fig. S8 in the ESI $\dagger$ ). The potential range of the CV scans was selected at 1.1-1.2 V vs. RHE which did not include obvious electrochemical features corresponding to faradaic current. As a result, the dependence of the current on the scan rate in this region for both electrodes was linear. The ECSA of the $\mathrm{Ni}(\mathrm{OH})_{2} \cdot 0.75 \mathrm{H}_{2} \mathrm{O}$ NSs, $\mathrm{Ni}(\mathrm{OH})_{2} \cdot 0.75 \mathrm{H}_{2} \mathrm{O}-\mathrm{CeO}_{2}$ $(30: 1) \mathrm{NSs}, \mathrm{Ni}(\mathrm{OH})_{2} \cdot 0.75 \mathrm{H}_{2} \mathrm{O}-\mathrm{CeO}_{2}(40: 1) \mathrm{NSs}, \mathrm{Ni}(\mathrm{OH})_{2}{ }^{-}$ $\cdot 0.75 \mathrm{H}_{2} \mathrm{O}-\mathrm{CeO}_{2} \quad(10: 1) \quad \mathrm{NSs}$, and $\mathrm{Ni}(\mathrm{OH})_{2} \cdot 0.75 \mathrm{H}_{2} \mathrm{O}-\mathrm{CeO}_{2}$ (2.5: 1) NSs were measured to be $3.4 \mathrm{~cm}^{2}, 7.74 \mathrm{~cm}^{2}, 6.33 \mathrm{~cm}^{2}$, $7.67 \mathrm{~cm}^{2}$, and $5.83 \mathrm{~cm}^{2}$ (shown in Fig. 4b). The ECSA of $\mathrm{Ni}(\mathrm{OH})_{2} \cdot 0.75 \mathrm{H}_{2} \mathrm{O}-\mathrm{CeO}_{2} \quad(30: 1)$ NSs is 2.3 times that of $\mathrm{Ni}(\mathrm{OH})_{2} \cdot 0.75 \mathrm{H}_{2} \mathrm{O}$ NSs, demonstrating that the introduction of Ce can remarkably enlarge the ECSA of $\mathrm{Ni}(\mathrm{OH})_{2} \cdot 0.75 \mathrm{H}_{2} \mathrm{O}$ NSs.

To understand the better intrinsic OER performance of $\mathrm{Ni}(\mathrm{OH})_{2} \cdot 0.75 \mathrm{H}_{2} \mathrm{O}-\mathrm{CeO}_{2} \mathrm{NSs}$, the activation energy of the OER was determined by Arrhenius plot: $\log (j)=-0.434 E_{\mathrm{a}} /(R T)+$ const, where $R$ is the Boltzmann constant $\left(8.315 \mathrm{~J} \mathrm{~g}^{-1} \mathrm{~mol}^{-1}\right.$ $\left.\mathrm{K}^{-1}\right), E_{\mathrm{a}}$ is the activation energy expressed in $\mathrm{J} \mathrm{g}^{-1} \mathrm{~mol}^{-1}$. Temperature related polarization curves of $\mathrm{Ni}(\mathrm{OH})_{2} \cdot 0.75 \mathrm{H}_{2} \mathrm{O}-$ $\mathrm{CeO}_{2}(30: 1) \mathrm{NSs}$ and $\mathrm{Ni}(\mathrm{OH})_{2} \cdot 0.75 \mathrm{H}_{2} \mathrm{O}$ NSs are shown in Fig. S9 in the ESI, $\dagger$ and corresponding Arrhenius plot at $\eta=150 \mathrm{mV}$ can be found in the Fig. 5a. The $E_{\mathrm{a}}$ is $6.06 \mathrm{~kJ} \mathrm{~mol}^{-1}$ for $\mathrm{Ni}(\mathrm{OH})_{2} \cdot 0.75 \mathrm{H}_{2} \mathrm{O}-\mathrm{CeO}_{2}(30: 1) \mathrm{NSs}$ and $9.77 \mathrm{~kJ} \mathrm{~mol}^{-1}$ for $\mathrm{Ni}(\mathrm{OH})_{2} \cdot 0.75 \mathrm{H}_{2} \mathrm{O}$ NSs. That is the $\mathrm{Ni}(\mathrm{OH})_{2} \cdot 0.75 \mathrm{H}_{2} \mathrm{O}-\mathrm{CeO}_{2}$
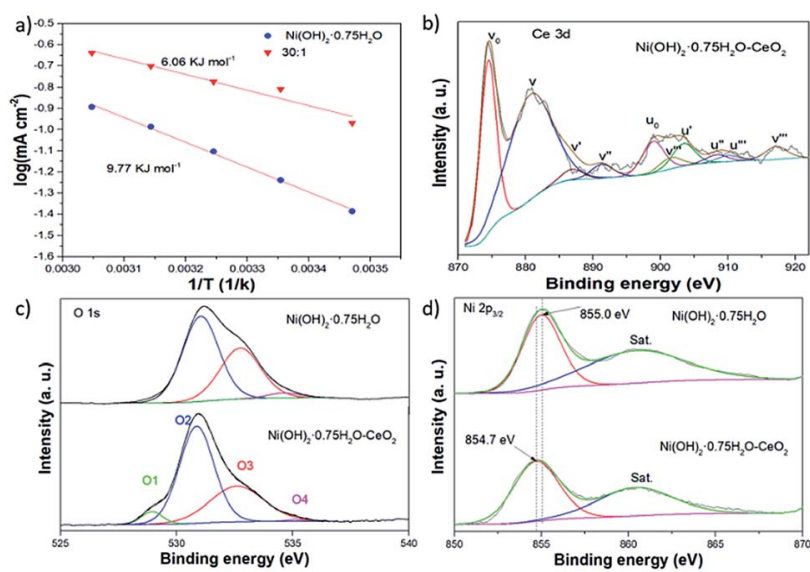

Fig. 5 (a) Arrhenius plots of $\mathrm{Ni}(\mathrm{OH})_{2} \cdot 0.75 \mathrm{H}_{2} \mathrm{O}$ and $\mathrm{Ni}(\mathrm{OH})_{2} \cdot 0.75 \mathrm{H}_{2} \mathrm{O}-$ $\mathrm{CeO}_{2}(30: 1)$, (b-d) XPS spectra of Ce 3d, O 1s, and Ni 2p. 
(30:1) NSs has a smaller apparent barrier height in the OER than $\mathrm{Ni}(\mathrm{OH})_{2} \cdot 0.75 \mathrm{H}_{2} \mathrm{O}$ NSs.

In order to analyze the chemical composition of the prepared $\mathrm{Ni}(\mathrm{OH})_{2} \cdot 0.75 \mathrm{H}_{2} \mathrm{O}$ NSs and $\mathrm{Ni}(\mathrm{OH})_{2} \cdot 0.75 \mathrm{H}_{2} \mathrm{O}-\mathrm{CeO}_{2}$ NSs electrocatalysts and to identify the chemical states of $\mathrm{Ni}, \mathrm{Ce}, \mathrm{O}$ elements in the samples, XPS measurements were carried out. As shown in Fig. 5b, XPS demonstrates that the element Ce mainly exists as $\mathrm{CeO}_{2}$, which is composed of $3 \mathrm{~d}_{5 / 2}\left(v_{\mathrm{n}}\right)$ and $3 \mathrm{~d}_{3 / 2}$ $\left(u_{\mathrm{n}}\right)$ spin-orbit components. ${ }^{30}$ For Ce $3 \mathrm{~d}$ of $\mathrm{CeO}_{2}$, the spectra can be deconvoluted into 10 peaks, which consist of two pairs of doublets $\left(v_{0} / u_{0}\right.$ and $\left.v^{\prime} / u^{\prime}\right)$ assigned to $\mathrm{Ce}^{3+}$ and three pairs of doublets $\left(v / u, v^{\prime \prime} / u^{\prime \prime}\right.$, and $\left.v^{\prime \prime \prime} / u^{\prime \prime \prime}\right)$ assigned to $\mathrm{Ce}^{4+}$, indicating the coexistence of $\mathrm{Ce}^{3+}$ and $\mathrm{Ce}^{4+}$ in the $\mathrm{Ni}(\mathrm{OH})_{2} \cdot 0.75 \mathrm{H}_{2} \mathrm{O}-\mathrm{CeO}_{2}$ NSs. ${ }^{42,43}$ For the $\mathrm{O} 2$ p spectra (shown in Fig. $5 \mathrm{c}$ ), peaks located at $530.87(\mathrm{O} 2), 832.60(\mathrm{O} 3)$ and $535.07(\mathrm{O} 4) \mathrm{eV}$ are ascribed to the lattice oxygen, oxygen defects, and adsorbed oxygen species (water molecules), accordingly. ${ }^{44-47}$ Meanwhile, a peak near $528.94 \mathrm{eV}$ is usually attributed to lattice $\mathrm{Ce}-\mathrm{O},{ }^{30}$ reconfirming the existence of $\mathrm{CeO}_{2}$. As shown in the $\mathrm{Ni} 2 \mathrm{p}_{3 / 2}$ spectra (Fig. $5 \mathrm{~d}$ ), the XPS results demonstrate that the element $\mathrm{Ni}$ of $\mathrm{Ni}(\mathrm{OH})_{2}$ $\cdot 0.75 \mathrm{H}_{2} \mathrm{O}$ NSs and $\mathrm{Ni}(\mathrm{OH})_{2} \cdot 0.75 \mathrm{H}_{2} \mathrm{O}-\mathrm{CeO}_{2} \mathrm{NSs}$ mainly exist as $\mathrm{Ni}(\mathrm{OH})_{2}$, containing $\mathrm{Ni}(\mathrm{II})$ species. However, there is a negative shift of $0.3 \mathrm{eV}$ for $\mathrm{Ni} 2 \mathrm{p}_{3 / 2}$ in the $\mathrm{Ni}(\mathrm{OH})_{2} \cdot 0.75 \mathrm{H}_{2} \mathrm{O}-\mathrm{CeO}_{2} \mathrm{NSs}$, compared to those in the $\mathrm{Ni}(\mathrm{OH})_{2} \cdot 0.75 \mathrm{H}_{2} \mathrm{O}$ NSs. Owing to the remarkable redox property of $\mathrm{CeO}_{2},{ }^{\mathbf{4 8 , 4 9}}$ This result suggests the electron transfer between $\mathrm{Ni}(\mathrm{OH})_{2}$ and $\mathrm{CeO}_{2}$, contributing to a strong electron interaction formed between $\mathrm{Ni}(\mathrm{OH})_{2}$ and $\mathrm{CeO}_{2}$, and accordingly enhancing the electrocatalytic performance.

\section{Conclusions}

In summary, cerium doped nickel hydroxide NSs were directly electrodeposited on CFP, and it exhibited superior OER activity compared to nickel hydroxide nanosheets. With the introduction of Ce, the optimized $\mathrm{Ni}(\mathrm{OH})_{2} \cdot 0.75 \mathrm{H}_{2} \mathrm{O}-\mathrm{CeO}_{2}$ NSs showed a tremendous increase in OER performance with the smallest $\eta_{100}$ of $320 \mathrm{mV}$ and Tafel slope of $126 \mathrm{mV} \mathrm{dec}^{-1}$ in alkaline electrolyte, as compared with that of $\mathrm{Ni}(\mathrm{OH})_{2} \cdot 0.75 \mathrm{H}_{2} \mathrm{O}$ NSs deposited in the same electrodeposition method. Meanwhile, the catalyst is stable for $45 \mathrm{~h}$ at high current density and $92 \%$ faradaic efficiency. The introduction of Ce brings strong electronic interactions between $\mathrm{Ni}(\mathrm{OH})_{2}$ and $\mathrm{CeO}_{2}$ and more electrochemically active sites, which should play an essential role in enhancing the OER activity.

\section{Conflicts of interest}

There are no conflicts to declare.

\section{Acknowledgements}

This research was financially supported by the National Natural Science Foundation of China (51772214, 51432006), the Ministry of Science and Technology of China (2011DFG52970), the Ministry of Education of China (IRT14R23), 111 Project (B13025), Jiangsu Province (2011-XCL-019 and 2013-479).

\section{References}

1 S. Chu and A. Majumdar, Nature, 2012, 488, 294.

2 R. Schloegl, Nat. Mater., 2008, 7, 772.

3 M. S. Dresselhaus and I. L. Thomas, Nature, 2001, 414, 332.

4 A. J. Bard and M. A. Fox, Acc. Chem. Res., 1995, 28, 141.

5 M. G. Walter, E. L. Warren, J. R. McKone, S. W. Boettcher, Q. Mi, E. A. Santori and N. S. Lewis, Chem. Rev., 2010, 110, 6446.

6 C. C. McCrory, S. Jung, I. M. Ferrer, S. M. Chatman, J. C. Peters and T. F. Jaramillo, J. Am. Chem. Soc., 2015, 137, 4347-4357.

7 I. Markoulaki, I. Papadas, I. Kornarakis and G. Armatas, Nanomaterials, 2015, 5, 1971-1984.

8 X. Long, J. Li, S. Xiao, K. Yan, Z. Wang, H. Chen and S. Yang, Angew. Chem., Int. Ed., 2014, 53(29), 7584-7588.

9 T. Sharifi, E. Gracia-Espino, X. Jia, R. Sandstrom and T. Wågberg, ACS Appl. Mater. Interfaces, 2015, 7(51), 2814828155.

10 L. J. Foruzin, Z. Rezvani, Y. H. Shishavan and B. Habibi, Int. J. Hydrogen Energy, 2018, 43(1), 150-160.

11 J. Li, G. Liu, B. Liu, Z. Min, D. Qian, J. Jiang and J. Li, Int. J. Hydrogen Energy, 2018, 43(3), 1365-1374.

12 J. A. Koza, Z. He, A. S. Miller and J. A. Switzer, Chem. Mater., 2012, 24(18), 3567-3573.

13 R. Chen, H. Y. Wang, J. Miao, H. Yang and B. Liu, Nano Energy, 2015, 11, 333-340.

14 X. Zheng, B. Zhang, P. De Luna, Y. Liang, R. Comin, O. Voznyy and T. Regier, Nat. Chem., 2018, 10(2), 149.

15 R. D. Smith, M. S. Prévot, R. D. Fagan, S. Trudel and C. P. Berlinguette, J. Am. Chem. Soc., 2013, 135(31), 1158011586.

16 B. Zhang, X. Zheng, O. Voznyy, R. Comin, M. Bajdich, M. García-Melchor and F. P. G. de Arquer, Science, 2016, 352(6283), 333-337.

17 R. Subbaraman, D. Tripkovic, K. C. Chang, D. Strmcnik, A. P. Paulikas, P. Hirunsit and N. M. Markovic, Nat. Mater., 2012, 11(6), 550.

$18 \mathrm{~J}$. W. D. Ng, M. García-Melchor, M. Bajdich, P. Chakthranont, C. Kirk, A. Vojvodic and T. F. Jaramillo, Nat. Energy, 2016, 1(5), 16053.

19 F. Dionigi and P. Strasser, Adv. Energy Mater., 2016, 6(23), 1600621.

20 L. Han, S. J. Dong and E. K. Wang, Adv. Mater., 2016, 28, 9266.

21 C.-C. Lin and C. C. L. McCrory, ACS Catal., 2017, 7, 443.

22 T. Tang, W.-J. Jiang, S. Niu, N. Liu, H. Luo, Y.-Y. Chen, S.-F. Jin, F. Gao, L.-J. Wan and J.-S. Hu, J. Am. Chem. Soc., 2017, 139, 8320.

23 G. Wu, W. X. Chen, X. S. Zheng, D. P. He, Y. Q. Luo, X. Q. Wang, J. Yang, Y. E. Wu, W. S. Yan, Z. B. Zhuang, X. Hong and Y. D. Li, Nano Energy, 2017, 38, 167.

24 J. X. Feng, H. Xu, Y. T. Dong, S. H. Ye, Y. X. Tong and G. R. Li, Angew. Chem., Int. Ed., 2016, 55(11), 3694-3698.

25 X. F. Lu, L. F. Gu, J. W. Wang, J. X. Wu, P. Q. Liao and G. R. Li, Adv. Mater., 2017, 29(3), 1604437. 
26 S. H. Ye, Z. X. Shi, J. X. Feng, Y. X. Tong and G. R. Li, Angew. Chem., Int. Ed., 2018, 57(10), 2672-2676.

27 J. A. Haber, Y. Cai, S. Jung, C. X. Xiang, S. Mitrovic, J. Jin, A. T. Bell and J. M. Gregoire, Energy Environ. Sci., 2014, 7, 682.

28 Y.-R. Zheng, M.-R. Gao, Q. Gao, H.-H. Li, J. Xu, Z.-Y. Wu and S.-H. Yu, Small, 2015, 11, 182.

29 J. W. D. Ng, M. García-Melchor, M. Bajdich, P. Chakthranont, C. Kirk, A. Vojvodic and T. F. Jaramillo, Nat. Energy, 2016, 1, 16053.

30 J.-X. Feng, S.-H. Ye, H. Xu, Y.-X. Tong and G.-R. Li, Adv. Mater., 2016, 28, 4698.

31 Z. Q. Liu, N. Li, H. Y. Zhao, Y. Zhang, Y. H. Huang, Z. Y. Yin and Y. P. Du, Chem. Sci., 2017, 8, 3211.

32 W. Gao, M. Yan, H.-Y. Cheung, Z. M. Xia, X. M. Zhou, Y. B. Qin, C.-Y. Wong, J. C. Ho, C.-R. Chang and Y. Q. Qu, Nano Energy, 2017, 38, 290.

33 X. Wang, Y. Yang, L. Diao, Y. Tang, F. He, E. Liu and S. Ji, ACS Appl. Mater. Interfaces, 2018, 10(41), 35145-35153.

34 M. Favaro, W. S. Drisdell, M. A. Marcus, J. M. Gregoire, E. J. Crumlin, J. A. Haber and J. Yano, ACS Catal., 2017, $7(2), 1248-1258$.

35 W. Gao, Z. Xia, F. Cao, J. C. Ho, Z. Jiang and Y. Qu, Adv. Funct. Mater., 2018, 28(11), 1706056.

36 K. Obata and K. Takanabe, Angew. Chem., Int. Ed., 2018, 57(6), 1616-1620.
37 S. Xu, C. Lv, T. He, Z. Huang and C. Zhang, J. Mater. Chem. A, 2019, 7, 7526-7532.

38 H. Zhang, H. Ning, J. Busbee, Z. Shen, C. Kiggins, Y. Hua and J. M. Zuo, Sci. Adv., 2017, 3(5), e1602427.

39 C. Lv, Z. Huang, Q. Yang, G. Wei, Z. Chen, M. G. Humphrey and C. Zhang, J. Mater. Chem. A, 2017, 5, 22805-22812.

40 C. Lv, Q. Yang, Q. Huang, Z. Huang, H. Xia and C. Zhang, J. Mater. Chem. A, 2016, 4, 13336-13343.

41 L. Jin, H. Xia, Z. Huang, C. Lv, J. Wang, M. G. Humphrey and C. Zhang, J. Mater. Chem. A, 2016, 4, 10925-10932.

42 C. Hardacre, G. M. Roe and R. M. Lambert, Surf. Sci., 1995, 326(1-2), 1-10.

43 B. Lin, Y. Liu, L. Heng, J. Ni, J. Lin and L. Jiang, Catal. Commun., 2017, 101, 15-19.

44 W. X. Guo, W. W. Sun and Y. Wang, ACS Nano, 2015, 9, 11462.

45 T. V. Thi, A. K. Rai, J. Gim and J. Kim, J. Power Sources, 2015, 292, 23.

46 B. P. Payne, M. C. Biesigner and N. S. McIntyre, J. Electron Spectrosc. Relat. Phenom., 2012, 185, 159.

47 J. Bao, X. D. Zhang, B. Fan, J. J. Zhang, M. Zhou, W. L. Yang, X. Hu, H. Wang, B. C. Pan and Y. Xie, Angew. Chem., 2015, 127, 7507.

48 C. T. Campbell and C. H. F. Peden, Science, 2005, 309, 713.

49 J. Paier, C. Penschke and J. Sauer, Chem. Rev., 2013, 113, 3949. 